University of California, Hastings College of the Law UC Hastings Scholarship Repository

Faculty Scholarship

2002

\title{
Our Economy of Mothers and Others: Women and Economics Revisited
}

Joan C. Williams

UC Hastings College of the Law, williams@uchastings.edu

Follow this and additional works at: http://repository.uchastings.edu/faculty_scholarship

Part of the Civil Rights and Discrimination Commons, and the Law and Gender Commons

\section{Recommended Citation}

Joan C. Williams, Our Economy of Mothers and Others: Women and Economics Revisited, 5 Journal of Gender 411 (2002).

Available at: http://repository.uchastings.edu/faculty_scholarship/820

This Article is brought to you for free and open access by UC Hastings Scholarship Repository. It has been accepted for inclusion in Faculty Scholarship

by an authorized administrator of UC Hastings Scholarship Repository. For more information, please contact marcusc@uchastings.edu. 


\section{Faculty Publications \\ UC Hastings College of the Law Library}

Author: Joan C. Williams

Source: Journal of Gender, Race \& Justice

Citation: 5 J. Gender Race \& Just. 411 (2002).

Title: $\quad$ Our Economy of Mothers and Others: Women and Economics Revisited

Originally published in JOURNAL OF GENDER, RACE \& JUSTICE. This article is reprinted with permission from JOURNAL OF GENDER, RACE \& JUSTICE and lowa College of Law, lowa City. 


\title{
Our Economy of Mothers and Others: Women and Economics Revisited
}

\author{
Joan Williams ${ }^{*}$
}

\section{INTRODUCTION}

A property lawyer coined the term "feminization of poverty" in the late 1970 s to highlight the prevalence of women among the poor. ${ }^{1}$ The feminization of poverty is an important topic in an age when the disparity in incomes is growing in the United States, and welfare is being "reformed"that is, from the view of many recipients, abolished as an entitlement. ${ }^{2}$ This take on the feminization of poverty, while important, is limited in a country with a current poverty rate of $11.8 \%{ }^{3}$ This article will argue that we need to fold the traditional debate on the proportion of women among the poor into a more sweeping analysis of the relationship between women and economics.

In doing this, we should follow the lead of the growing international awareness, which focuses more broadly on women's relationship to economic security. ${ }^{4}$ Statistics show that women are the poorest of the

* Professor of Law, American University, Washington College of Law, Director, Program on Gender, Work \& Family. This paper was written for The Journal of Gender, Race \& Justice's fifth annual symposium, The Feminization of Poverty (Oct. 23, 2000). Many thanks to Professor Sherry Colb for helpful comments and a close reading, and to the other members of the Symposium, the Rutgers Faculty Speaker Series, the California Western School of Law, and the American University, Washington College of Law Faculty Speaker Series, where this article was presented in draft form. Particular thanks to my colleague Professor Walter Effross for suggesting I use the phrase "mothers and others" as the title of this article.

1. Diana Pearce, The Feminization of Poverty: Women, Work and Welfare, 11 URB. \& SoC. ChANGE Rev. 28 (Winter/Spring 1978).

2. See, e.g., Child Support and Welfare Costs: Interview with Mary Jo Bane, Former Assistant Secretary for Children and Families, U.S. Department of Health and Human Services, 4 GEO. PUB. POL'Y REv. 9, 12 (1998); Vada Waters Lindsey, The Burden of Being Poor: Increased Tax Liability? The Taxation of Self-Help Programs, 9 KAN. J.L. \& PUB. POL'Y 225 (Winter 1999); Cynthia Negrey et al., Job Training Under Welfare Reform: Opportunities for and Obstacles to Economic Self-Sufficiency Among Low Income Women, 7 GEO. J. ON POVERTY L. \& POL'Y 347 (Summer 2000); Nicole Stelle Gamett, The Road from Welfare to Work: Informal Transportation and the Urban Poor, 38 HARV. J. ON LEGIS. 173 (Winter 2001).

3. U.S. Census BuReau, Poverty Rate Lowest IN 20 Years, household INCOME at RECORD HIGH, CENSUS BUREAU REPORTS (Sept. 26, 2000), at http://www.census.gov/PressRelease/www/2000/cb00-158.html.

4. See, e.g., The United Nations Commission on the Status of Women, at http://www.undp.org/fwcw/csw.htm (last visited Jan. 25, 2002); see also The United Nations 
world's poor. Women are not only fifty-nine percent of those in poverty and seventy percent of those in extreme poverty, ${ }^{5}$ but they also "earn less than a tenth of the world's income and own less than one percent of the world's property." 6

If our goal is an analysis of women's economic welfare, what better place to start than with Charlotte Perkins Gilman's Women and Economics? ${ }^{7}$ This classic treatment, published in 1898 , established the framework we still use today. Gilman's central focus is on women's dependence:

[W]omen, as a class, neither produce nor distribute wealth ... women, as individuals, labor mainly as house servants, are not paid as such, and would not be satisfied ... if they were so paid ... wives are not business partners or co-producers of wealth with their husbands, unless they actually practice the same profession ... they are not salaried as mothers, and that it would be unspeakably degrading if they were, what remains to those who deny that women are supported by men? ${ }^{8}$

And, tartly, "the female of the genus homo is supported by the male." He is her food supply. ${ }^{9}$

Gilman has no doubt that women are supported by men. This support is both an affront to their dignity ("the pitiful dependence of the human female" ") and corrosive of their character ("the sluggish and greedy disposition bred of long ages of dependence"ll). Her solution is to restructure the tasks performed by wives along the industrial model. For instance, houses without kitchens will mean that professional chefs will cook the meals. Even childcare will be professionalized under this model. ${ }^{12}$ The

Division for the Advancement of Women, at http://www.un.org/womenwatch/daw/ (last visited Jan. $25,2002)$.

5. See Jane Lee Saber, Women and the International Monetary Fund, 5 ILSA J. INT'L \& COMP. L. 335, 337 (Spring 1999) (stating that among the 1.2 billion people living in extreme poverty within undeveloped countries, 59\% are female); UNIFEM, STRENGTHENING WOMEN'S ECONOMIC CAPACITY, at http://www.unifem.undp.org/economic.htm (last visited Apr. 2, 2001) (stating women represent $70 \%$ of the 1.3 billion people that live in absolute poverty and when nearly 900 million women have less than $\$ 1$ a day, the association between gender inequality and poverty remains a harrowing reality).

6. See Gillian Moon, Trade and Women in Developing Countries, at http://www.caa.org.au/horizons/h13/trade.html (last visited Sept. 17, 2000) (citing Erika Gottfried, Note, Mercosur: A Tool to Further Women's Rights in the Member Nations, 25 FORDHAM URB. L.J. 923, 925, $953(1998))$.

7. Charlotte Perkins Gilman, WOMEn AND Economics (Dover Publ'ns, Inc. 1998) (1898).

8. Id. at 9 .

9. Id. at 18 .

10. Id. at 19.

11. Id. at 76 .

12. Id. at 104-10. 
Gilman tradition, echoed virtually unchanged some sixty years later by Betty Friedan in The Feminine Mystique, dominates popular imagery of American feminism to this day. ${ }^{13}$ Feminism today is still associated with an insistence on employment for women with day care centers as the solution for the conflict between work and family demands.

I have argued that the Gilman model ${ }^{14}$ is flawed because it accepts too readily three basic elements of the housewife/breadwinner system historians call domesticity. First, it accepts the current construction of paid labor, which reflects the ideal of a worker who starts to work in early adulthood and works for forty years straight, taking no time off for child-bearing or child-rearing. ${ }^{15}$ Second, it accepts the dichotomy between home and work, and the notion that household work is not "work."16 Reva Siegel documented that before the nineteenth century, society openly acknowledged the economic value of women's household labor. ${ }^{17}$ However, the advent of domesticity's new sex/gender arrangements erased the economic value of household work. ${ }^{18}$ Consequently, today there is an attitude among homemakers that they "don't work."19 Finally, the Gilman model embraces the privatized theory that reproductive work is a private responsibility and not a public necessity. ${ }^{20}$

We need to change each element of domesticity in order to create a new model for the analysis of women and economics. I will begin with a broad overview of the elements for this new model. Then I will describe each element in greater detail. Finally, I will propose an analytic framework that

\section{BETTY FRIEDAN, THE FEMININE MYSTIQUE (1963).}

14. I call the Gilman model "the full-commodification" model. See JOAN WiLliaMS, UNBENDING GENDER: WHY FAMILY AND WORK CONFLICT AND WHAT TO DO ABOUT IT (2000) [hereinafter UNBENDING GENDER].

15. Id. at 2.

16. Id. at 31-33 (citing historians Nancy Cott and Jeanne Boydston).

17. See Reva B. Siegel, Home as Work: The First Women's Rights Claims Concerning Wive's Household Labor, 1850-1880, at 103 YALE L.J. 1073, 1092 (1994) ("In the nineteenth century, wives' economic contribution to the household was no longer as 'visible' as it had been in more subsistence-oriented agrarian economies of the colonial and Revolutionary eras.").

18. Id. at 1093.

19. See id. at 1092-93 ("As it became more common for men to exchange their labor for money-wages, production for use came to be identified as a distinctly female activity, associated with the social, but not economic, maintenance of family life. Census measures of the economy that appeared in the aftermath of the Civil War characterized such labor as 'unproductive,' and, consistent with this gendered valuation of family labor, excluded women engaged in incomeproducing work in the household from the count of those 'gainfully employed.' In so doing, they gave official expression to what were already deeply entrenched assumptions of popular discourse, which denied that wives' work was work.").

20. For brilliant and forceful contestations of this premise, see Martha Fineman, Cracking the Foundational Myths: Independence, Autonomy, and Self-Sufficiency, 8 AM. U. J. GENDER SOC. PoL'Y \& L. 13 (2000); see also NANCY Folbre, THE INVISIBLE HEART 14 (2001) (discussing women's reproductive rights). 
changes gender arrangements in both market work and family work.

\section{THE BASIC SKETCH}

Discussions of women and poverty tend to focus on "welfare," the social safety net designed for the impoverished. Yet, the social safety net affects only women's relationship to a small fraction of our economy. Welfare programs constitute a tiny fraction, three to four percent, ${ }^{21}$ of the federal budget; much more important are "entitlement" programs such as social security, unemployment insurance, our elaborate system of tax and other social expenditures. ${ }^{22}$

If the goal is to analyze women's relationship to the public distribution of wealth, it makes no sense to focus our attention only on a small fraction of government budgets. We need to bring the analysis of other government programs (now considered topics of interest only to specialists) into the mainstream of gender research. Thus far, the only government program other than welfare that has received extensive gender analysis is tax. Critical tax theory can provide many of the tools we need for analysis of the public sector. ${ }^{23}$ This is an important step, but we need to go further. To gain a balanced picture of women's relationship to economic security, we need to examine women's relationship to private as well as public wealth.

To the extent that we discuss women's relationship to the private economy, the tendency is to focus on women's workforce participation. Yet this approach itself is gendered. The economic security of most men depends on their employment status, but the economic security of many women does not. American women still do eighty percent of the childcare, ${ }^{24}$ and this

21. Office of the Assistant Secretary for Planning and Evaluation, U.S. House OF REPRESENTATIVES, THE 2000 GREEN BOOK, at http://aspe.gov/2000gb/appeni.txt (last visited Apr. 2, 2001).

22. Stanley S. Surrey, Tax Incentives as a Device for Implementing Government Policy: A Comparison with Direct Government Expenditures, 83 HARV. L. REV. 705 (1970) (introducing the policy of tax incentives).

23. See, e.g., Nancy C. Staudt, Taxing Housework, 84 GEO. L.J. 1571, 1574 (1996) ("Tax scholars have previously noted that the current tax structure, in effect, encourages women to perform more housework than if the economic gains of all labor were taxed; however, they have failed to acknowledge that exempting household labor from the tax base also denies women important social welfare benefits directly tied to taxation."); Nancy E. Shurtz, Critical Tax Theory: Still Not Taken Seriously, 76 N.C. L. REV. 1837, 1887 (1998) ("The chief contribution this new scholarship can make is to shift the terms of taxation discourse to bring a broader array of concerns to the policy table in the hope that taxation may be employed as a more powerful and flexible tool in the effort to elevate social welfare through a higher commitment to social justice.").

24. JOHN P. ROBINSON \& GEOFFREY GODBEY, TIME FOR LIFE: THE SURPRISING WAYS AMERICANS USE THEIR TIME 104 (1997); see also SHARON HAYS, THE Cultural CONTRADICTIONS OF MOTHERHOOD 100 (1996) (stating that in married couples, mothers contribute seventy-four percent of the total hours spent in direct childcare). I do not have data for single mothers, but one assumes they do more. 
family work often affects their participation in paid work. ${ }^{25}$ For this reason, in order to analyze women's relationship to private wealth, we need to consider not only their paid but also their family work. In the United States this boils down to a discussion of divorce law, but the real issue is one of who owns what within the family.

To summarize, we need to widen our analysis of women and economic security to include the social safety net and the disproportionate percentage of women among the poor. We also need to consider how other government wealth-distribution programs, from social "entitlements" to the tax system, systematically favor men over women. Finally, we need to analyze women's relationship to private as well as public wealth through a consideration both of women's relationship to paid work, and their entitlements based on family relationships.

\section{A. Access to Economic Security through Market Work}

Today two statistics frame the way we look at women and paid work. The first is women's workforce participation, a demographic measure that documents the demise of the breadwinner/housewife model as women entered the workforce. ${ }^{26}$ The second is the wage gap, which measures the gap between the wages of men who work full-time against the wages of women who work full-time. ${ }^{27}$ Both statistics reflect the Gilmore model; they are designed to measure the extent to which women are in the labor force working shoulder to shoulder with men, as ideal workers who become employed in early adulthood, and remained employed, full-time and fullforce, for forty years straight.

While the work patterns and wages of women without children are looking increasingly like those of ideal-worker men, the same is not true of mothers. If we look at mothers during the key years of career advancement, aged twenty-five to forty-four, two out of three do not perform as ideal workers even in the minimal sense of working forty hours per week all year. What is more dramatic is that ninety-two percent work less than fifty hours per week. $^{28}$ In an age where virtually all good jobs require full-time work, and many of the best jobs require overtime, mothers are cut out of the labor

25. See UNBENDING GENDER, supra note 14, at 2 (stating that although family work affects the welfare participation of many mothers, it is also true that many mothers in the workforce perform as ideal workers much the same as non-mothers).

26. Barbara R. BERGMANN, THE ECONOMC EMERGENCE OF WOMEN 5 (1986).

27. UNBENDING GENDER, supra note 14, at 66-86; see also THE NATIONAL COMMITTEE ON PAY EQUTTY, LITTLE PROGRESS IN CLOSING WAGE GAP IN 2000 (noting that women make seventythree percent of men's eamings), at http://www.feminist.com/fairpay/f_wagegap.htm (last visited Jan. 22, 2002).

28. Thanks to Suzanne Bianchi and Liana Sayer for calculating these figures from the Bureau of Labor Statistics \& BUREaU of the CENSUS, March 1999 CuRRENT Population SURVEY, at http://www.bls.census.gov/cps/cpsmain.htm (last visited Jan. 27, 2002). 
pool for many desirable jobs, blue- as well as white-collar.

\section{B. Economy of Mothers in Comparison to Others}

Women without children earn ninety percent of the wages of men, but mothers earn only sixty percent of the wages of fathers. ${ }^{29}$ The "family gap" between the wages of mothers and other adults increased during the $1980 \mathrm{~s}^{30}$ and may still be rising among the least privileged women. ${ }^{31}$ If we look not at women's workforce participation but at whether they perform as ideal workers along with men, what emerges is a picture of the fragile hold women have on market work in a society where nearly ninety percent of women become mothers during their working lives. ${ }^{32}$

In short, a focus on wage gap and workforce participation figures tends to exaggerate the extent to which women have reached economic equality. After all, two-thirds of working women work less than forty hours per week. ${ }^{33}$ Therefore, the wage gap statistic comparing women who work fulltime with men who work full-time grossly overestimates the extent of women's equality. Workforce participation statistics are equally misleading: consider the woman lawyer who dropped out of her legal career and ran a part-time quilt business from her home. ${ }^{34}$ Though she was "in the workforce," she remained firmly marginalized and economically vulnerable. We need new economic measures that document our economy of mothers and others. ${ }^{35}$

At a deeper level, we need to reassess Gilman's assumption that the key to economic equality is for women to perform as ideal workers along with men while childcare is delegated to professional childcare workers. As a model for economic equality this has proved to be morally troubling and of limited effectiveness. ${ }^{36}$ Particularly in an age of high overtime, we need to

29. Id.

30. Jane Waldfogel, Understanding the "Family Gap" in Pay for Women with Children, 12 J. ECON. PERSP. 137, 143 (Winter 1998).

31. Jane Waldfogel \& Susan E. Mayer, Gender Differences in the Low-Wage Labor Market, in FINDING JOBS: WORK \& WELFARE REFORM 214-15 (David E. Card \& Rebecca M. Blank eds., 2000).

32. UNBENDING GENDER, supra note 14, at 2 (quoting Jane Waldfogel, The Effect of Children on Women's Wages, 92 AM. SOC. REV. 209, 209 (1997)).

33. See id. (citing the computations of Professor Manuelita Ureta).

34. Id. at 1 .

35. In the Ideal Worker Project, funded by the Alfred P. Sloan Foundation, I will be working with demographer Suzanne Bianchi to generate a new data series designed to document mothers' marginalization.

36. The model is morally troubling, in a society without the political will to provide publicly subsidized childcare, because it consigns many children to market childcare of questionable quality. National InSt. of Child Health \& Human Dev., The NICHD Study of EaRly ChildCare (1998). Rather, the current system solves privileged women's gender troubles by taking advantage of 
go back and rethink how we define the "committed" or "responsible" worker.

The problem with pinning our hopes for women's equality on a strategy of having women perform as ideal workers, as June Carbone said long ago, is that "it leaves out the small matter of who will take care of the children." ${ }^{37}$ The real issue is that our ideals at work do not fit with our ideals for family life. In a society with the longest hours of overtime in the industrialized world, longer even than Japan's, the ideal-worker norm clashes with our sense of what we owe to children. Fathers who work fulltime work an average of forty-eight hours per week. ${ }^{38}$ This increases when combined with their average commutes, ${ }^{39}$ meaning that they may well be gone from home ten or more hours each weekday. Who among us thinks the ideal way to raise children is for both parents to be gone from nine a.m. to seven, eight or nine p.m.?

We are caught in the clash of two social ideals: the ideal-worker norm on the job, and the norm of parental care at home. This clash combines with gender performance norms that engenders in most women the desire to be a "real mother" (complete with milk, cookies, and carpool), ${ }^{40}$ and into most men the desire to be a "real man" (which includes performing as an ideal worker to the extent his race, class, and personality allow him to do so). The end result is that gender has proved unbending. The economy of mothers and others will not change until we redefine the ideal worker and restructure market work, and thereby, redefine our work ideals so that they are more in sync with our traditions of nurturance. The key here is family responsive policies. $^{41}$

\section{Access to Economic Security through Family Work}

One out of four mothers is still a housewife during the key years of career advancement. ${ }^{42}$ Economic security for many women clearly does not depend on paid work but on entitlements gained within the family. Moreover, homemakers are not the only ones whose economic security depends on entitlements gained through family life. Women who work part-

their privileged position in class and racial hierarchies. See UNBENDING GENDER, supra note 14, at 145-76.

37. June Carbone, Income Sharing: Redefining the Family in Terms of Community, 31 Hous. L. REV. 359 (Summer 1994).

38. JAMES A. LEVINE \& TODD L. PITTINSKY, WORKING FATHERS: NEW STRATEgIES FOR BALANCING WORK AND FAMILY 25 (1997).

39. Id.

40. See generally HAYS, supra note 24; Naomi R. Cahn, Gendered Identities: Women and Household Work, 44 VILL. L. REV. 525 (1999).

41. See discussion infra Part IV.

42. UNBENDING GENDER, supra note 14 , at 2 . 
time can expect to make a fraction of what their husbands or ex-husbands make, given the depressed wages of part-time workers. ${ }^{43}$ Even women who work full-time often have wages that are comparatively low. ${ }^{44}$ The end result is that, in the average American family, the father still earns nearly seventy percent of the family income. ${ }^{45}$ Thus, economic security depends on entitlements gained within the family relationships not only for homemakers but also for many women who work part-time or even full-time outside the home.

The only existing conversation for discussing this topic is the "new theory of alimony" debate in family law; ${ }^{46}$ however, the issues at stake here require more than a narrow focus on alimony, which has traditionally been based on need rather than on ownership ${ }^{47}$ and has never been awarded to more than a small fraction of women (currently around eight percent). ${ }^{48}$ Instead, we need a more sweeping consideration of who owns what within the family.

To undertake this analysis, we need to examine domesticity's definition of paid work as "real work," while defining equally important care work as "not working." I like to quote one mother:

I get so sick of people asking me, "Do you work?" Of course I work! I've got five children under ten! I work twenty-four hours a day! But of course they mean, "Do you work for pay, outside your home?" Sometimes I hear myself say, "No, I don't work," and I think, "that's a complete lie!"49

It is a complete lie and one with important social implications. A key tenet of domesticity is that wives are "supported" by men who "work." In fact, the only reason a father can perform as an ideal worker is that he typically is supported by a flow of childcare and other family work from his partner (whether they are currently married, or ever have been). Once we notice the

43. Id. at 72 .

44. See Bureau of Labor Statistics, Labor Force Statistics From the CURRENT POPULATION SURVEY (Oct. 20, 2000), available at $\mathrm{http} / / \mathrm{www} . \mathrm{bls} . g o v /$ news.release/wkyeng.t02.html (noting that the median weekly earnings for fulltime wage and salaried women age twenty-five and over in the third quarter of 2000 was $\$ 519$, compared to $\$ 700$ for men).

45. Thanks to Steve Hipple for calculating these figures from the CURRENT POPULATION Survey, Bureau of Labor Statistics \& Bureau of the Census (Mar. 1999), http://www.bls.census.gov/cps/cpsmain.htm.

46. For a comprehensive listing of the contributions to this debate, see Joan Williams, Symposium On Divorce and Feminist Legal Theory: Is Coverture Dead? Beyond a New Theory of Alimony, 82 GEO. L.J. 2227, 2228 n.2 (1994).

47. See generally LesLIE HARRIS ET AL., FAMILY LAW 370-401 (1996) (providing an overview of spousal support after divorce with excerpts from case law and secondary authorities).

48. See UNBENDING GENDER, supra note 14, at 122.

49. Id. at 33 . 
father's dependence on that flow of family work, we can see that the chief family asset in most households, the ideal-worker wage, reflects not only the father's paid work but also the mother's family work. ${ }^{50}$

Note how this analysis flips the traditional understanding of who is dependent upon whom; ${ }^{51}$ the common understanding, accepted by Gilman, is that women depend on men. ${ }^{52}$ In order to change domesticity's erasure of household work, we need to place front and center the idea that family work is work, not leisure, and that it is an integral part of the overall economy. ${ }^{53}$

One would think that an asset reflecting the work of two family members would be jointly owned. But that's not what happens today. In divorce courts, in the economy of gratitude in intact marriages, ${ }^{54}$ and in many government benefits programs, ${ }^{55}$ the husband typically is treated as the sole owner of the ideal-worker wage. ${ }^{56}$

There is a little bit of wealth redistribution throughout family law but not much; ${ }^{57}$ alimony is rare, temporary, and generally low because most families have so little savings; no property distribution rule has much effect. $^{58}$ Two prominent economists estimate that fathers as a group pay only six percent of their income in child support, although some fathers pay a lot more. ${ }^{59}$ In this context, it should not be surprising that nearly forty percent of divorced mothers end up living in poverty. ${ }^{60}$ When we take a step back from this analysis, we can see that what we have, and what we are exporting through globalization, is a system in which men specialize in paid work, work linked with ownership, while women specialize in family work, leisure linked with economic vulnerability.

The logic is clear. When you define the ideal worker as someone without responsibility for children, you set up a childcare system that pushes

50. The implication here is that a homemaker married to a rich man will receive more than one married to a poor one. Changing our notion of who owns what within the family, unfortunately, cannot address the unconscionably wide disparities of income in the United States.

51. Compare Fineman, supra note 20 (defining caretakers as subsidizing the state).

52. GILMAN, supra note 7 , at 5 (describing the common belief that although men make and distribute wealth, women eam their share as wives).

53. See generally JEANNE BOYDSTON, HOME AND WORK (1990).

54. See ARLE HOCHCHILD, THE SECOND SHIFT 110-27 (1989) (discussing the "economy of gratitude").

55. UNBENDING GENDER, supra note 14 , at 131.

56. Id. at 115.

57. Id. at 121-22.

58. Id.

59. E-mail from Sara McClanahan, Professor of Sociology and Public Affairs, Princeton University, and Irv Garfinkel, Professor of Contemporary Urban Problems, Columbia University, to Joan Williams, Professor of Law, American University, Washington College of Law (Jan. 11, 2000) (on file with author).

60. DEMI KURTZ, FOR RICHER FOR POORER 3 (1995). 
the primary caregivers to the margins of economic life. In a few European countries the government steps in to redistribute wealth to women and children. ${ }^{61}$ However, the absence of such a system in most other regions leads to predictably high levels of child and maternal poverty. In the United States, eighty percent of those living in poverty are women and children. ${ }^{62}$ Few governments in developed countries have the political desire to save women and children from the gendered logic of the private economy; some European countries have outstanding supports for caregivers, ${ }^{63}$ but many other developed countries, notably the United States, do not. ${ }^{64}$ Even fewer developing countries have the resources to do so. Unless we want to export our economy of mothers and others through globalization, we need to redefine the relationship of women to private wealth, not only in the United States, but worldwide.

\section{ACCESS TO ECONOMIC SECURITY THROUGHT THE GOVERNMENT}

Completing our analysis of women and economic security requires an analysis of women's relationship not only to private wealth, but also to government wealth. Scholars of the social safety net have led the way in delineating how government wealth distribution programs affect women. ${ }^{65}$ The next step is to move from an analysis of women to an analysis of gender. When the series of programs commonly known as "welfare" is seen through the lens of domesticity, what emerges is a particularly pernicious example of how women's family work is erased and treated as leisure. Thus, the impoverished mother who takes three buses at midnight to get her asthmatic child to the hospital is defined as lazy. ${ }^{66}$

\section{A. The Linked Fate of Women and Children}

An analysis that starts with domesticity also highlights the way our economic system links the fate of women and children. A system that provides for the care of children by economically marginalizing their caregivers is one that systematically impoverishes children as well as women. This is in sharp contrast to the view that women's equality will hurt

61. Joan Williams, Afterword: Exploring the Economic Meanings of Gender, 49 AM. U. L. REV. 989 (2000).

62. UNBENDING GENDER, supra note 14 , at 115.

63. See ANN Crittenden, The Price of Motherhood 239-49, 264 (2001) (finding that Sweden and France have extensive government sponsored family-support programs).

64. See Barbara R. Bergmann, Saving Our ChILdREn from Poverty 91-116 (1996) (detailing the shortfall of U.S. government programs designed to aid families and children).

65. Katharine Silbaugh, Turning Labor into Love: Housework and the Law, 91 Nw. U. L. REV. 1, 23-26 (1996).

66. Williams, supra note 61 , at 1005. 
children's chances. In fact, domesticity in a society allergic to government redistribution, such as the United States, is a sex/gender system that systematically impoverishes children. One out of five U.S. children and one out of two of African-American children are living in impoverished conditions. $^{67}$

\section{B. Domesticity and Government Redistribution Programs}

In addition to providing the groundwork for an analysis of welfare that focuses on women, domesticity offers some significant insights into government redistribution programs other than those that form part of the social safety net. Mary $O^{\prime}$ Connell provides a particularly insightful analysis. ${ }^{68} \mathrm{O}$ 'Connell points out that in the United States, a three-tiered system of economic security exists. ${ }^{69}$ Her analysis is important so it should be quoted at length:

The greatest security belongs to those whose attachment to paid work is lengthy, uninterrupted, and highly remunerative.... A second mode of access allows some persons to claim economic security derivatively - that is, through the labor force participation of another individual.... [T] his mode of access produced a hodgepodge of entitlements, fraught with gaps, that frequently fails to provide needed protection to the recipient. Finally, those who do not engage in paid work, and who lack access based on a derivative basis, must look to statutes providing means-tested benefits for their economic security. These benefits are chronically underfunded and their receipt is often stigmatized. ${ }^{70}$

This three-tier system is gendered, with the upper tier inhabited predominantly by men, and the two lower tiers staffed almost exclusively by women. $^{71}$

To complete the O'Connell analysis, we not only need to build on critical tax theory but also must go much further. The distribution of government benefits plays a great, if not greater, role in defining women's relationship to economic security. ${ }^{72}$ As $\mathrm{O}^{\prime}$ Connell points out, government

67. Curtis J. Berger \& JoAN C. WILLIAMS, PROPERTY: LAND OWNERShIP AND USE 40 (4th ed. 1997).

68. See Mary E. O'Connell, On the Fringe: Rethinking the Link Between Wages and Benefits, 67 TUL. L. REv. 1421 (May 1993); see also Mary Becker, Patriarchy and Inequality: Towards a Substantive Feminism, 1999 U. CHI. LEGAL F. 21 (1999); Silbaugh, supra note 65.

69. O'Connell, supra note 68, at 1423-24.

70. Id.

71. Id. at 1449-70.

72. See Heidi Hartmann \& Catherine Hill, Strengthening Social Security for Women, A Report from the Working Conference on Women and Social Security, 1999 INST. FOR WOMEN'S POL'Y RES. 1, 7 (stating more women are dependent on social security, a government distribution, 
benefits include more than the obvious candidates: Social Security, unemployment insurance, and worker's compensation. An analysis of how government actions allocate wealth needs to include the tax subsidies given to private health care and pension plans. ${ }^{73}$ Today these benefits reflect the model of an ideal worker who begins full-time work in early adulthood and works uninterrupted until retirement. This model is designed around men's bodies and life patterns; therefore, it discriminates against women. According to estimates by the Older Women's League, by 2030, a majority of women still will not work in the patterns required to receive Social Security. ${ }^{74}$

The solutions are complex, but two basic principles emerge. First, social entitlements should be based equally on the two important kinds of work most adults do: paid work and family work. Social security and other benefits should not be earned only through paid work, but also through family work. Second, benefits linked to paid work should not be limited to ideal workers as traditionally defined. Health insurance policy waiting periods, ERISA vesting rules, Social Security recency requirements and the thirty-five-year work-life rule should be abolished or redesigned so that they are not disproportionately skewed toward men. Currently men earn social entitlements, such as Social Security, and private benefits such as health insurance and private pensions, that are less available to women. ${ }^{75}$

\section{DESIGNING Policies to CHANGE THE RELATIONSHIP OF WOMEN AND ECONOMICS}

This completes the basic analysis. The next question is this: how do we change the relationship of women and economic security? To change that relationship, we can change one or more of three basic relationships. First, we can change the relationship between employers and employees. Second, we can change entitlements within the family. Third, we can change the configuration of the public and private spheres.

\section{A. Changing the Relationship between Employers and Employees.}

One approach is to change the relationship of employers and employees. We can accomplish these changes by requiring workplaces to take account of the important family work responsibilities of their employees. To do this, we need to go far beyond current "family friendly" policies and rethink how we define the ideal worker. Most large employers today have such policies, but, according to one survey, only three to five

because they "earn less and live longer than men").

73. O'Connell, supra note 68 , at $1505-06$.

74. Id. at 1497.

75. See generally id. at 1454-71. 
percent of workers use them. ${ }^{76}$ Why? The widespread perception, often true, is that workers who do so often pay a steep price. "[W]hen you work parttime or temporary," said one secretary, "they treat you differently, they don't take you serious."77 Many policies explicitly affect promotion, as when law firms take part-time attorneys off the partnership track, a practice that is still very common. ${ }^{78}$ Professional workers, who are disproportionately likely to have access to work/family benefits, ${ }^{79}$ also often find that "the only responsible way to work part-time is to work full-time"; they find their hours creeping up despite the fact they are being paid less, and many find themselves with less desirable work assignments to boot. ${ }^{80}$ Some employers enjoy a "family friendly" dividend when they pocket a percentage of a parttime worker's salary without hiring anyone else to handle the part-timer's workload. Needless to say, this practice has fueled a backlash by child-free workers against family friendly policies. ${ }^{81}$

What would restructured work look like if it did not carry the penalties it now does? A baseline is the principle of proportionality: proportional pay, benefits, and advancement for part-time work. This is particularly important in mandatory overtime economies that, in effect, wipe most mothers out of the labor pool for good jobs. It is also vitally important in white-collar contexts, because the "executive schedule" has sharply limited the number of women who survive in business (more than ninety-five percent of upperlevel management is still men), ${ }^{82}$ law (eighty-seven percent of law firm partners are still men), ${ }^{83}$ academics (more than seventy-four percent of tenured professors are still men), ${ }^{84}$ and many other traditionally masculine professions. The principle of proportionality is also important in good bluecollar jobs. Such jobs tend to have a high benefit load (up to forty percent of

76. WILLIAMS, supra note 14 , at 94 .

77. Id. at 72.

78. Interview with members of the Washington, D.C. legal community, for the Project on Attorney Retention (the PAR Project) funded by the Alfred P. Sloan Foundation and the Women's Bar Association of the District of Columbia (Oct. 11, 2000) (developing a model reduced hours schedule for Washington, D.C., law firms). The final report based on these interviews is available at PAR Project, Balanced Hours: Effective Part-Time Policiees for Washington Law FIRMS http://www.pardc.org (hereinafter PAR Report).

79. UNBENDING GENDER, supra note 14 , at 33.

80. Id. at 72-75; PAR Report, supra note 78, at 18.

81. See, e.g., ELINOR BURKETT, THE BABY BOON (2000).

82. UNBENDING GENDER, supra note 14 , at 67 (quoting Deborah L. Rhode, The "NoProblem" Problem: Feminist Challenges and the Cultural Change, 100 YALE L.J. 1731, 1765 n.168 (1991)).

83. Id. (quoting ABA COMM'N ON WOMEN IN THE PROFESSION, WOMEN IN THE LAW: A LOOK AT THE NUMBERS 3 (1995)).

84. Joan C. Williams, How the Tenure Track Discriminates Against Women, CHRON. HIGHER EDUC., Oct. 27, 2000, available at http://chronicle.com/jobs/2000/10/2000102703c.htm. 
wages), ${ }^{85}$ which gives employers the motivation to require long hours of existing employees rather than to hire new ones. In addition, traditionally masculine blue-collar jobs rarely have part-time tracks, and, as we have seen, mothers rarely work jobs with lots of overtime. Consequently, scheduling plays a significant role in keeping women out of high-paying, traditionally masculine blue-collar work (which is not to say that other factors, notably sexual harassment, do not also play a role). ${ }^{86}$ Finally, the principle of proportionality can offer significant benefits to the working poor, who often can find only part-time work, with depressed wage rates, no benefits, and no chance for advancement. At Shopper's Food Warehouse, for example, part-timers are ineligible for promotion to management positions. ${ }^{87}$

To implement the principle of proportionality requires us to rethink the ways we define an ambitious, committed, valuable worker. But family responsive workplaces require other changes as well. For example, in interviews with more than three hundred women in Iowa, sociologist Jennifer Glass found that the women she spoke with, many of them working class, expressed the need for flextime so that their work hours would match with the hours of their childcare provider, as well as time off for medical appointments, child illnesses (infants average six doctor's visits a year), ${ }^{88}$ school plays and conferences. They also stated the need for an adequate supply of quality, affordable childcare. ${ }^{89}$

Voluntary programs that persuade employers to change traditional ways of doing business hold significant promise, particularly in an age of high employment. 90 The "business case" reflects the fact that current business practices impose steep costs on employers. ${ }^{91}$ Most dramatic are the costs of high attrition among mothers in full-time or overtime work, and among fathers in high-overtime environments. Human resources professionals report that replacing a worker costs between seventy-five and one hundred and fifty percent of the worker's annual salary, with more highly trained workers costing more to replace. As a result, every time five associates leave a Washington, D.C. law firm, more than a million dollars walk out the

85. O'Connell, supra note 68 , at 1425 . Note that this statistic is for all jobs, not just bluecollar jobs.

86. UNBENDING GENDER, supra note 14 , at 78-81.

87. Julie McWilliams, Address at the Industrial Relations Research Association National Public Policy Forum (June 22, 2000).

88. JODY HeYMANN, THE WIDENING GAP 73 (2000).

89. Interview with Jennifer Glass, Chair of Department of Sociology, University of Iowa, in Iowa City, Iowa (Oct. 13, 2000).

90. United States unemployment rate is only $4.2 \%$ (statistic taken from month of February 2001). See Bureau of Labor Statistics, OUR ECONOMY at a Glance, http://stats.bls.gov/eag/eag.us.htm. (last visited Apr. 2, 2001).

91. PAR Report, supra note 78, at 7-8. 
door. $^{92}$

Family responsive policies tend to reduce absenteeism. ${ }^{93}$ When the baby is sick, someone is going to take her to the doctor and will have to call in sick to do so. But if employees have the option of taking time off formally, through flextime or part-time, absenteeism rates fall. ${ }^{94}$

Productivity may rise as well. In 1930, the Kellogg Company implemented six-hour workdays as a coping strategy for Depression-caused unemployment. $^{95}$ After implementing the change, the company discovered that worker productivity increased an average of three to four percent. ${ }^{96}$ The point is an intuitive one: having been one of those lawyers who worked thirteen hours a day, I can tell you that my productivity in hour thirteen was not the same as my productivity in hour three.

A final, and understudied, element of the business case for family responsive policies is the correlation between employee satisfaction, employee loyalty, and client loyalty. Employers who have effective family responsive policies in an era when employee loyalty is hard to come by find that employees who feel their family needs are being addressed can be fiercely loyal, as in the case of the moving company that experienced zero turnover when they offered telecommuting and other benefits, ${ }^{97}$ or the dermatology company that experienced zero turnover once it provided a twenty percent discount to the neighboring family care unit, instituted flexible work hours and provided parent education classes. ${ }^{98}$ Employee loyalty is important in itself because it reduces attrition and increases motivation, but it is also important for another reason: study after study has shown a correlation between retaining employees and retaining clients. ${ }^{99}$

92. UNBENDNG GENDER, supra note 14 , at 88.

93. See id. at 91.

94. Id. (quoting WORK \& FAMILY CONNECTION, INC., WORK \& FAMILY: A RETROSPECTIVE $130(1995))$.

95. JULIET B. SCHOR, THE OVERWORKED AMERICAN 154-55 (1992).

96. Id. (" $[T]$ he efficiency and morale of our employees [are] so increased, the accident and insurance rates are so improved, and the unit cost of production is lowered that we can afford to pay as much for six hours as we formerly paid for eight.").

97. Interview with Jim Johnson, President, Johnson Moving and Storage, in Denver, Colo. (May 11, 2000) [hereinafter Johnson Interview].

98. See UNBENDING GENDER, supra note 14, at 88.

99. See Keith Hammonds, Balancing Work and Family, Bus. WK., Sept. 16, 1996, at 74 (demonstrating that higher employee retention rates led to a seven percent increase in customer retention); Patricia Sellers, Keeping the Buyer you Already Have, FORTUNE, Sept. 22, 1993, at 56 (linking employee satisfaction to employee retention, which ultimately results in customer loyalty); Patricia Sellers, What Customers Really Want, FORTUNE, June 4, 1990, at 58 ("Customer retention and employee retention feed one another."); Sue Shellenbarger, Companies Are Finding It Really Pays To Be Nice to Employees, WALL ST. J., July 22, 1998, at B1 ("We came up with conclusive evidence that improving employee satisfaction will satisfy customers better and, in turn, improve financial results...."); Watson Wyatt, Strategy@Work (Oct. 20, 2000), at http://www.watsonwyatt.com/ strategyatwork/editions/2000/2000_04_08.asp (noting that for one 
Again, for lawyers this is intuitive: we have all seen clients walk out the door when "their" lawyer leaves.

Yet the fact is that twenty years of arguing the business case has gotten us to where we are today: we have family responsive policies that look good on paper but businesses seldom use them. One study found that current policies are used by only three to five percent of workers. ${ }^{100}$ We do not need to graft marginal corrections onto an antiquated system, ${ }^{101}$ rather we need to rethink how we define the committed, ambitious worker.

Here is a radical proposition: employers should reward productivity. We should choose and promote workers based on the quality of their work product, not on the schedule they can keep. Why? In a society where schedule correlates tightly with gender, a system that systematically rewards people based on their ability to keep the schedule kept by most men, but few women, discriminates against women.

To explore this, let's return to the definition of the ideal worker who takes no time off for child-bearing or child-rearing. Who needs no time off for childbirth? And, in a society where women still do the large bulk of the childcare, who needs no time off for child-rearing? Designing workplaces around men's bodies and men's traditional lifestyles is discriminatory.

Note that this is gender, not sex discrimination: what is at issue is not a disadvantage that attaches to all women, but one that attaches to all caregivers. That is, men who do not conform to traditional breadwinner patterns are disadvantaged equally, indeed sometimes more, than are women. ${ }^{102}$ They also suffer from gender discrimination in the form of taunts and comments that communicate that a "real man" does not take parental leave. ${ }^{103}$ Martin Malin has suggested that the Family \& Medical Leave Act's prohibition on employer interference with leave rights is a possible tool for combating this workplace hostility toward paternal use of parental leave. ${ }^{104}$

The importance of adding this analysis to the business case is two-fold.

company, meeting employee satisfaction goals is as important as meeting financial goals).

100. UNBENDING GENDER, supra note 14, at 94 (quoting Deborah L. Rhode, Fleeing Home for the Comforts of an Office, NAT'L L.J., Oct. 6, 1997, at A23).

101. LotTe Bailyn, Breaking the Mold: Women, Men, and Time IN the New CORPORATE WORLD 67 (1993) ("All of these [work-family policy] responses are certainly helpful, but they are still based on the assumptions that employees' family concerns can be treated on the margins, conceptually distinct from the primary goals of the organization.").

102. See Martin H. Malin, Fathers and Parental Leave, 72 TEX. L. REV. 1047, 1049 (1994) (citing instances where men are unable to take parental leave).

103. See id. at 1077-78 ("Employer sensitivity to the need to accommodate workers' family responsibilities is increasing steadily. Unfortunately, many employers' willingness to make such accommodations is limited to women workers. Men's accommodation requests are often met by, 'Your wife should handle it.' ... Employers are not the only source of workplace hostility. Coworker hostility can generate powerful peer pressure. Such peer pressure can intimidate and deter fathers from taking leave.").

104. See id. (illustrating the need for workplace accommodations to suit the family responsibilities of men). 
First, many employers are people of good will, who are shocked at the thought that they are systematically disadvantaging women. Take Jim Johnson, president of the moving company Johnson Storage \& Moving Co., mentioned above. After Johnson heard me speak, he went right back and asked his human resources people whether his practice of not giving benefits to part-timers affected mostly women. He was horrified to hear that it did, and immediately offered proportional benefits to part-timers to the extent his insurance company allowed him to do so. ${ }^{105} \mathrm{We}$ should not forget that, in the United States, discrimination language is a language of social ethics.

Second, of course, discrimination language shifts our sense of who is entitled to what. A sense that a failure to accommodate family responsibilities could change contract negotiations, if unions could point out the way that the systematic devaluation of part-time work systematically discriminated against women. Who is entitled to what?

In addition, in certain cases discrimination analysis can be translated into legislation, or into litigation under existing federal or state antidiscrimination statutes. ${ }^{106}$ This is still in the early stages, but plaintiffs' employment lawyers have begun to take cases that challenge either outright discrimination against mothers (through a disparate treatment, intentional infliction or hostile environment theory) ${ }^{107}$ or discrimination against those working part- or flex-time (through a disparate impact theory) ${ }^{108}$ or violations of the Family \& Medical Leave Act. ${ }^{109}$ Cumulatively, these cases can begin to change perceptions about work/family conflict, from the view that it reflects only "mother's choice," to the view that it often signals gender discrimination against men as well as against women.

\section{B. Changing Entitlements within the Family}

The standard approach to changing entitlements within the family in this country has been to try to change the allocation of family work between men and women. This strategy has achieved some success. Men now contribute more family work: but women still do between sixty-six and eighty percent. ${ }^{110}$

But what is also clear is that, just as there are two groups of womensome of whom do virtually all of the childcare, and others who share more

105. Johnson Interview, supra note 100.

106. For further information, see Gender, Work \& Family Project's webpage at http://www.genderwork.org.

107. See, e.g., Wynn \& Wynn, P.C. v. Mass. Comm'n Against Discrimination, 729 N.E.2d 1068 (Mass. 2000).

108. See, e.g., Capruso v. The Hartford, Inc., No. 01-4250 (S.D.N.Y. filed Apr. 6, 2001).

109. See Knussman v. Maryland, 16 F. Supp.2d 601 (D. Md. 1998).

110. See UNBENDING GENDER, supra note 14, at 2; see also HAYS, supra note 24, at 100 (stating that mothers' caregiving amounts to seventy-four percent of "direct childcare"). 
equally with their partners - there also has emerged a split among men. Some men, notably in families that use the "tag team" approach, where both parents work but one parent cares for the children while the other is at work, do significant amounts of childcare. ${ }^{111}$ But other men still do very little. This picture is further complicated by class differences, with less privileged men doing significantly more childcare than more privileged white men, presumably because the tag-team approach appears to be most common among working-class families. ${ }^{112}$

This picture suggests that statistics averaging the amount of childcare performed by men are less than informative. What we need are statistics that break out tag-teamers from other men. I am told that recent time diary studies make this possible. We shall see what information they yield. ${ }^{113}$ All this detail aside, the message that comes through loud and clear is that the strategy of shifting the allocation of family work within the household has been met with limited success. Forty years after women started bargaining for equality within the household, it is estimated that they continue to perform between sixty-six and eighty percent of the housework. ${ }^{114}$ We need to be more thoughtful about why women continue to perform the majority of household work, and this is where three areas of literature should prove helpful. One is the booming literature on masculinity, which can help us understand the gender pressures on men that make them resist the hydraulic pressures within individual households to share work more equally. ${ }^{115}$ The

111. Jacqueline L. Salmon, 'Hi, Dad! Bye, Mom' - Couples Try Parenting in Shifts, WaSH. Post, Aug. 2, 1998, at A1 ("About 20 percent of the nation's two-parent, two-income households with children are tag-team families, according to the U.S. Census Bureau. And experts say the arrangement will become even more widespread in coming years as the growing demand for 24-hour services generates more jobs with nonstandard hours."); see also KATHLEEN GERSON, No MAN's LAND 22-37 (1993) (finding that masculinity has become more variegated-that some men do a lot whereas others do very little).

\section{Lillian B. RuBin, FAMiLies on the FAULt LiNE 93-94 (1994).}

113. Interview with Beth Mattingly, Graduate Student, Sociology Dept., University of Maryland (Oct. 5, 2000).

114. This estimate is comprised of different sources with varying sites. See, e.g., SCOTT COLTRANE, FAMILY MAN: Fatherhood, HousewORK, AND GENDER EQUITY 53 (1996) (noting that even after men's increased participation is taken into account, women still contribute, on average, three times the amount of housework than do men); HAYS, supra note 24, at 100 (stating that in married couples, mothers contribute seventy-four percent of the total hours spent in direct childcare); JAMES A. LeVINE \& TODD L. PITTINSKY, WORKING FATHERS: New STRATEgIES for BALANCING WORK AND FAMILY 26 (1997) ("The household gap is closing not just because fathers are doing more at home, but because mothers are doing more in the workplace and less at home.... That is exactly what Rosalind Barnett found in her study of dual-earner couples. "Altogether women spend more time on household chores (about 3.7 hours a day) compared to the men (about three hours a day)...."); Joseph H. Pleck, Are "Family Supportive" Employer Policies Relevant to Men?, in MEN, WORK, AND FAMILY 219-20 (Jane C. Hood ed., 1993) (stating that recent statistics reveal that men participate in approximately one-third of the housework). What emerges from these discrepancies is an immanently clear picture: although the statistics from the 1990's vary, male and female household roles are nowhere near equal.

115. See, e.g., MICHAEL S. KIMMEL, MANHOOD IN AMERICA: A CULTURAL HiSTORY (1996) (describing the historical and psychological roles of American men). 
second is the growing literature on "gate-keeping" by women, including Naomi Cahn's important insight that mothers often refuse to let go of the sole-source supplier (primary caregiver) role because their identity as women is tied up with that particular gender performance. ${ }^{116}$ Finally, there is another literature that does not, but should, exist: a literature that explores the relationship of gender and class. One reason gender has proved so unbending is because gender performances play a central role in class formation. ${ }^{117}$ Gender performances help create class status, as when the ideology and practice of intensive mothering creates high-human-capital kids. ${ }^{118}$ The available cultural idioms for the performances of class are very gendered, as when families consider having the mother at home a signal of having "arrived" at middle-class status. 119

The most basic fact about the typically privatized, psychologized, American strategy of solving the work/family conflict by changing the allocation of family work, is that it has failed. It is time to shift attention away from women's psychology onto structural economic relations: the structure of market work and the issue of who owns what within the family. Both above and in other contexts, ${ }^{120} \mathrm{I}$ have discussed these issues as they relate to families in the United States. Here I only want to add that, although divorce law is the key locus for changing traditional notions of who owns what within the family in the United States, in other countries inheritance laws may be the key to gaining access to wealth for women. In many parts of Africa, inheritance laws are often guided by customary law, which often considers the woman to be the property of her husband and therefore ineligible to inherit anything. ${ }^{121}$ In Latin America, as another example, inheritance laws focus on the children; the wife is effectively disinherited. ${ }^{122}$

116. See Cahn, supra note 40 , at 534-35.

117. UNBENDING GENDER, supra note 14, at 34-37.

118. See HAYS, supra note 24, at 115-18.

119. UNBENDING GENDER, supra note 14 , at 153-61.

120. See Williams, supra note 46; see also Joan Williams, Wives Own Half? Winning for Wives After Wendt, 32 CONN. L. Rev. 249 (Fall 1999).

121. See Celestine I. Nyamu, How Should Human Rights and Development Respond to Cultural Legitimation of Gender Hierarchy in Developing Countries, 41 HARV. INT'L L.J. 381 (Spring 2000) (explaining that in parts of anglophone Africa, customary law is officially recognized and will, in many cases, prevail over the national constitution); see also Leslie Kurshan, Rethinking Property Rights as Human Rights: Acquiring Property Rights for Women Using International Human Rights Treaties, 8 AM. U. J. GENDER SOC. POL'Y \& L. 353, 359-60 n.34-42 (2000) (describing various examples of African countries where women cannot inherit their husband's property).

122. See Steven Hendrix, Property Law Innovation in Latin America with Recommendations, 18 B.C. INT'L \& COMP. L. REV. 1, 13-14 (1995) (noting that even though women ostensibly have equal property rights in civil law jurisdictions, local magistrates "often give all the real property to the sons, irrespective of the law"). 


\section{Changing the Relationship between the Public and Private Spheres}

In this context, once again, we need to recognize the extent to which conversations within American feminism have been framed within an intensely privatized frame. The United States stands virtually alone among developed nations in its conviction that child-rearing is a private frolic rather than a social enterprise of vital importance. ${ }^{123}$ The National Partnership on Women and Families has taken the lead in its inexhaustible lobbying to persuade the American Congress to provide for American parents the kinds of parental leaves that are almost universal in developed nations outside the United States. ${ }^{124}$ The limited nature of what has been achieved, an unpaid Family \& Medical Leave Act that, at best, accounts for only three months of child-rearing, a task that lasts twenty years, is attributable more to the inhospitableness of the soil than lobbyists' skill. ${ }^{125}$

If the Scandinavian approach of mandating leaves is one approach to changing the configuration of the public and private spheres, the other is the approach articulated by Martha Fineman, Nancy Dowd and others: to establish a new social entitlements program that provides social subsidies to all caregivers. ${ }^{126}$ As I have argued elsewhere, social subsidies for caregivers are extremely important as a measure to alleviate our high levels of childhood poverty; they would also contribute to economic security for many women. ${ }^{127}$

\section{Feminist Jurisprudence and Care Work.}

There seems to be a controversy brewing within feminist jurisprudence over which of these three approaches is best. ${ }^{128}$ This should not surprise us, given the argument culture of academic life, in which the natural way to engage is to criticize. But isn't the easy answer that we need to work on all three? We need to try to change the relationship between employers and employees; we need to change accepted notions of who is entitled to what

123. Williams, supra note 61 , at $988-90$.

124. See THE NATIONAL PARTNERShIP ON WOMEN AND FAMILIES, $a t$ http://www.nationalpartnership.org (last visited Oct. 19, 2000).

125. Family \& Medical Leave Act of 1993, 29 U.S.C. $\$ 2601$ (1994).

126. Fineman, supra note 20 , at 26-27; see also NANCY E. Dowd, REDEFINING FATHERHOOD 220-25 (2000) (discussing the disregard of the family in economic and public policies); EVA FEDER KITTAY, LOVE's LABOR: ESSAYS ON WOMEN, EQUALITY, AND DEPENDENCY $140-46$ (1999) (discussing the need to change public policy and liberal theory to take dependency into account).

127. Joan Williams, Exploring the Economic Meanings of Gender, 49 AM. U. L. REV. 987, 988- 90 (2000).

128. See, e.g., Symposium on the Structures of Care Work, 76 CHI.-KENT L. REV. 1389 (2001); Vicki Schultz, Life's Work, 100 CoLUM. L. REV. 1881 (2000); Responses to Life's Work, 102 COLUM. L. REV. (forthcoming Apr. 2002). 
within the household; we need to fight the bizarrely privatized vision that two prominent sociologists have dubbed the "children as pets" approach, in which children are viewed as just another consumer item in which the public need have no more interest in than in the acquisition of another Porsche. ${ }^{129}$

All three projects contribute to the deconstruction of domesticity both as an ideology, and as a system of structuring market work and delivering child services. As feminists we need to be very thoughtful about what Deborah Tannen has called the "argument culture," the tendency to engage through attack. ${ }^{130}$ Inevitably, we will disagree sometimes, and we need intellectual room to explore those disagreements. However, we also need to remember most feminists who are doing their job right will be struggling for resources and credibility. We can safely assume that our articles, grant proposals and tenure applications will not receive rave reviews from conservatives in law and economics, advocates, doctrinalists, or many others who, though they are people of good faith, are much the same as the American public because feminists make them nervous. In this context, we can count on one vote, or more, against our articles, grant proposals and tenure applications for the simple reason that we are feminists. Is it not better in this context to stick together?

\section{CONCLUSION}

In conclusion, we need to move away from an emphasis on the disproportionate share of women among the poor, the wage gap, and the "new theory of alimony" debate, towards a more sweeping analysis of women and economics. When we do, we will find ourselves rewriting Charlotte Perkins Gilman's approach by rejecting certain key elements of domesticity she adopted without comment. These include the breadwinner structure of market work, in which the ideal worker is someone who has few significant responsibilities for children; the assumption that homemakers are dependent and somehow lacking; and the notion that the costs of childrearing (in a system that provides for children's care by economically marginalizing their caregivers) are "naturally" privatized onto individual mothers without significant social support.

This is not to belittle Gilman's accomplishment: we stand on the shoulders of giants. Like Gilman, we can only proceed by mobilizing certain elements of domesticity against others. Thus Martha Fineman urges socialization of the costs of child-rearing in the name of Mother. ${ }^{131}$ I urge a restructuring of work around the norm of parental care. We will attempt to flip domesticity against itself in the manner of a judo master, using its own

129. FOLBRE, supra note 20, at 109.

130. DEBorah TANNEN, THE ARgument CULTURE 7-8 (1998).

131. Martha Albertson Fineman, The Neutered Mother, the Sexual Family, \& OTHER 20TH CENTURY TRAGEDIES 228 (1995). 
momentum to throw it off balance. We embrace what we view as its relatively innocuous elements to target what irks us most. This is inevitable in a culture where domesticity is so pervasive. To make our arguments seem plausible and persuasive, they need to resonate, and much of that resonance turns out to stem from the sex/gender system all of us, including Gilman, are striving to replace. 